\title{
Reclamation of devastated landscape in the Karviná region (Czech Republic)
}

\author{
Jan Havrlant, Luděk Krtička \\ Department of Social Geography and Regional Development, Faculty of Science, University of Ostrava, Chittussiho Str. 10, \\ 71000 Ostrava, Czech Republic \\ E-mail address: jan.havrlant@osu.cz
}

\begin{abstract}
The article deals with the recent positive changes in the industrial landscape of the Karviná region in a broader context. The Karviná region has been the most important part of the coal-bearing Ostrava-Karviná District. Since the industrial revolution, the position of the primary mining area has brought a dynamic economic development and a great concentration of population into the fast-growing conurbation cities, particularly between 1950s and 1980s. However, the dominant coal mining and processing has had a negative impact on the environment, the character and utilization of the landscape. Many environmental, socioeconomic and other problems did not become fully evident until the social changes at the turn of $1980 \mathrm{~s}$ and 1990s. At present, a great attention is being paid to the reclamation of the affected landscape. As a result, the region is starting to change its unflattering image of an industrial and problematic area devastated by coal extraction for the better after many years. The various forms of land reclamation, modification of water bodies, construction of new sports and recreational facilities and so on are bringing a gradual improvement of the environment in the region, creating a new cultivated landscape that can be used, among other things, for various forms of tourism and relaxation.
\end{abstract}

KEY WORDS: Karviná region, devastated area, reclamation, utilization of landscape

\section{Introduction}

The Karviná region (Fig. 1), as a part of the Ostrava residential conurbation, has been the most important part of the mining Ostrava-Karviná District for almost two centuries. From the physical-geographical point of view, it takes up the eastern part of the Ostrava Basin that passes into the Podbeskydí highland in the south. Since the industrial revolution, the position of the primary mining area has brought a dynamic economic development and a great concentration of population into the fast-growing conurbation cities during the $19^{\text {th }}$ and $20^{\text {th }}$ centuries as well as a whole range of social, economic, environmental and other problems that did not become evident until the second half of the $20^{\text {th }}$ century and that changed the image of the local towns. Significant social changes took place towards the end of the $20^{\text {th }}$ century, including economic transformation, industry restructuring and so on. Today, changes in the utilization of landscape are taking place in this territory affected by the mining activity. After many years, the Karviná region is starting to change its image of an industrial and troublesome region with a landscape devastated by coal mining. The objective of the contribution is to provide an overview of the recent changes in the mining landscape in the Karviná region, of the devastating impacts of coal mining on the environment and particularly of the changes in the affected landscape caused by the various forms of reclamation, as well as to show the benefits of the new utilization of the industrial landscape as a result of the growing cooperation of Ostrava-Karviná Mines Company and other parties involved at the regional and local levels. 


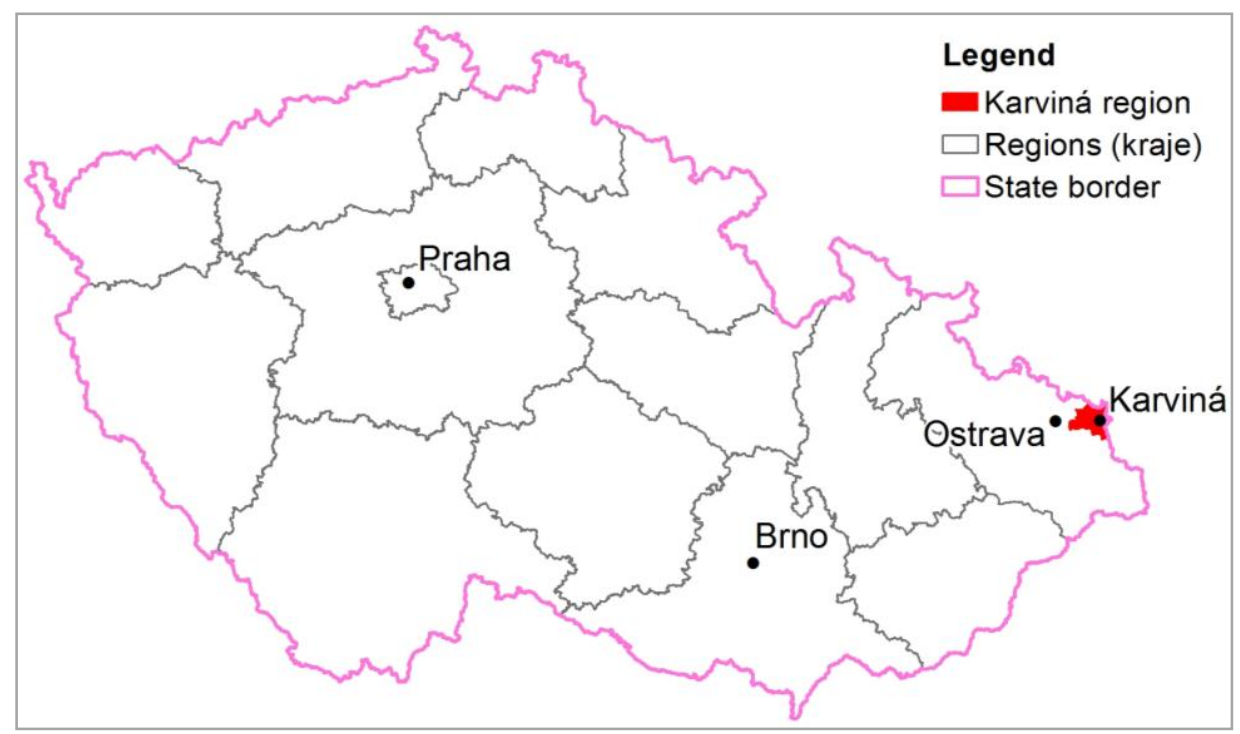

Fig. 1. Localisation of Karviná region in the Czech Republic

\section{Theoretic-methodological approaches to the issue of reclamations}

\subsection{Reclamation of landscape}

Reclamation of landscape affected by mining can be perceived as a restoration of landscape that allows its utilization. The reclamation of landscape helps renew the values of the devastated area; it eliminates the consequences of mining. It represents an essential and very costly maintenance of the landscape. The aim of reclamation activities is to create a new cultural landscape that will provide people with an ecologically balanced, hygienically suitable, aesthetically impressive and recreationally valuable environment with a new natural, cultural and economic potential (ŠTÝs, 1998). It is a process that starts with a technical decontamination of the area, shaping and other terrain modifications, followed by a long-term process of greening the landscape with biological restoration, leading to the overall revitalization of the affected landscape.

Revitalization of landscape affected by mining and industrial activity is perceived, in the narrow sense, as improvement of the overall condition of the ecosystem in the affected area. As far as anthropogenic landscape is concerned, this mainly includes the restoration of naturally valuable biotopes.

The issue of landscape reclamation and revitalization was first monitored in the main mining and industrial European regions in the second half of the $19^{\text {th }}$ century when hard and soft coal started to be widely exploited at the time of the industrial revolution. In Bohemia, the Mining Law passed in 1854 imposed the liability to return the land damaged by mining into its original condition. However, the first, more complex "general reclamation plans for affected areas" in the major mining districts of Czechoslovakia (North Bohemia and Ostrava-Karviná District) did not come into existence until 1960s. These general plans and other related zoning documents for variously-sized territorial units became the strategic documents for solving the reclamation of areas affected by raw material extraction. In the Czech Republic, the reclamation of devastated land was attended to by the specialized state company called "Rekultivace" from 1960s and then the DIAMO state company from the beginning of 1990s. The company provides elimination of consequences after mining and redeveloping, technical and biological reclamations after the closedown of the mining activity. In addition to the specialized company, the mining companies also participate in the reclamation actions, which they implement in their mining areas on the basis of the amended Act No. 44/1988 Coll. ${ }^{1}$ In the Ostrava-Karviná

\footnotetext{
1 The approval of mining and technological plans of the Ostrava-Karviná Mining Company also include the calculation of costs of the obliteration of the consequences of the mining activity. The Company is liable for creating financial reserves for the caused mining damages and for financial compensation of mining plants provided to the affected municipalities, cities, representatives of civil initiatives, owners of land and objects and for reclamation constructions pursuant to Mining Act No. 44/1988 Coll. From the beginning of 1990s, mining organizations allocate payments from the extracted minerals to the accounts of the relevant mining authority and the mining authority then transfers a part of the funds to the accounts of the cities and municipalities that are located in the mining areas. The funds are then released as ecological subsidies for the reclamation of the affected land on the basis of requests of the mining organizations (OKD, 2013).
} 
District, it is the Ostrava-Karviná Mines Company. As for the professional scientific circles dealing with landscape reclamation, the team of employees of the reclamation department of the former Most Mining Company under the supervision of Stanislav Štýs excels in this area. Štýs is an author of more than 400 publications focused on the issue. Many of them have been published abroad, particularly in countries where the issue of extracting minerals, reclamation and revitalization of the affected landscape is topical, such as Germany, Poland, Russia and others. Important works by Štýs include Reclamation of Areas Affected by Mining (ŠTÝs, 1981); or Strategies and Methods of Reclaiming Areas Affected by Mining (ŠTÝs, 1989) and others.

The issue of the influence of deep hard coal mining on the landscape in the Ostrava Region with regard to the impacts on the natural and anthropogenic landscape elements was studied by a group of people at the Institute of Geonics of the Czech Academy of Sciences in Brno (MiKulík ET AL., 2004). At the same time, the Institute of Geonics also participated in the preparation of a set of maps related to the issue. Another cartographic work of the Institute of Geonics is the Maps of influence of reduction of deep hard coal mining in the Czech part of the Upper Silesian Coal Basin on the surface and the environment (MARTINEC ET AL., 2003). The monograph of the Institute of Geonics (MARTINEC ET AL., 2006) in which the authors also discuss the development of reclamation activities during 1960s - 1980s and after 1990 provides a more integrated approach to the issue of the influence of reduction of coal mining on the environment. The work also focused on the new methods of landscape reclamation applied in the Ostrava-Karviná District, Kladno District and South Moravian District.

Currently, some university departments also focus on the issue of anthropogenic changes, reclamation of mining landscape and its potential future utilization. In the Czech Republic, these include: VRÁBLÍKOVÁ ET AL., (2009) at the Faculty of Environment of the J. E. Purkyně University in Ústí nad Labem; BARTƯŇKOVÁ (2012), CHUMAN (2013) at the Faculty of Science of the Charles University in Prague; ŠIŘINA (2003), RACLAVSKÝ (2001), МАCHÁČEK (2009) at the Technical University of Ostrava; or HAVRLANT M. $(1967,1979)$, HAVRLANT J. (1999, 2010), PopelKová (2009) at the Faculty of Science of the Ostrava University and others.

In Poland, the issue of anthropogenic relief transformation, reclamation and revitalization of landscape is monitored by many experts, particularly in the Upper Silesian Coal Basin. At the end of the $20^{\text {th }}$ century, these were ŻMUDA (1973),
JANKOWSKI (1986, 2000), JANKOWSKI \& HAVRLANT M. (1999), SZCZYPEK (1995), KUPKA ET AL. (2005, 2008). In the past few years DoMAŃSKI (2000), UBERMAN (2004), DULIAS $(2004,2010)$, DULIAS \& KUPKA (2010), KOPEC (2010), LORENS (2010), ChMiELEWSKA $(2009,2012)$ and others have been discussing various methods of reclamation, utilization of wastes from the mining activity and complete revitalization of the degraded areas, including Polish and German cities and the changes in their functions. In Germany, the issue of reclamation and revitalization of landscape and restructuring of areas affected by mining and industrial activities is largely discussed mainly in the regions of the Ruhr, Rhineland, Leipzig, Halle and Cottbus. The experts that were interesting in this topic in the second half of the 20 $0^{\text {th }}$ century were, for example, Konrad, Strzodky, Pisk (ŠTÝs 1981); and in the past few years these are BEHR (2003), HERTER (2006), NEUMANN \& TRETTIN (2012) and others. The most projects focused on the reclamation of affected areas (in 20 locations) have been implemented in the Ruhr (in the Emsche river basin) from the 1960s up to this day GANSER (1993), FUCHS (1999) and others also dealt with new development and construction activities in this old industrial region. The issue of the restoration of degraded areas was also discussed in Great Britain, for example by WALKER \& Del Moral (2003) and others. In Russia and Ukraine, Motorina, Ovčinnikov and Fedosejev (ŠTÝs, 1981) were interested in the issue as early as in the 1970s.

\subsection{Theoretical concepts and reclamation methods}

The theoretical concepts and reclamation methods applied in the mining regions of Europe are not very different today. The basic characteristics of reclamation modifications of landscape include the principle of the integral unity in mining and the following reclamation of the affected area. The conditions for the following landscape reclamation are already created during the preparation and implementation of mining. At the same time, the strong relation to the social and economic factors in the concerned territory is also applied. In the industrial landscape, this is demonstrated by the close cooperation with the zoning technical activities of the involved businesses and institutions through the application of a wide spectrum of traditional as well as unusual methods of landscape reclamation (such as forestry, agricultural, recreational etc.).

The methods of the Czech reclamation school are the most acknowledged in the world. They are 
given as examples to institutions in Germany, Poland, Russia and other countries dealing with this issue (ŠTÝs, 1998). Formerly preferred reclamation methods focused on the restoration of the original agricultural landscape into its optimal state. However, the current reclamation concepts in the Czech Republic and its neighbouring countries are showing some changes. A suitable regional proportionality of various reclamation methods for the affected areas is fundamental.

Modern landscape reclamation concepts strive to create a new cultural, ecologically balanced landscape with stabilized forest, agricultural and hydric ecosystems that are to become the new ecological centres or biological corridors with the occurrence of various plant and animal species (including protected ones) in the regional system of ecological stability.

Technical redevelopment of the area is the foundation of complete reclamation of the devastated area. It includes all terrain modifications, including technical modifications of slopes (antierosion and stabilization measures), hydro-technical modifications (modifications of flows, construction of dams) and hydro-melioration modifications of the landscape. In the devastated area, these also include stripping and backfill of soil and tailings, construction of various operating structures, reconstruction or construction of communication and engineering networks etc. The basic technical redevelopment is followed by the process of biotechnical reclamation of the landscape, which comes in various forms, usually as agricultural or forest reclamation.

Agricultural reclamation is implemented by planting field or special artificial crops in the prepared surface. Lately, however, the formerly used agricultural crops (cereals, root-crops, legumes and so on) have been replaced with permanent grass vegetation (grass mixtures, clover) in the industrial regions. A specific type of agricultural landscape reclamation is orchard reclamation with planting of various artificial crops (fruit orchards, vineyards etc.).

Forest reclamation represents the foundation and care for planted various types of forest crop. Forest crops, particularly in the devastated landscape, are an important stabilization element in the ecological system in relation to their aesthetic, hygienic, climatic, hydric, anti-erosive, redeveloping and recreational function (ŠTÝs, 1998). Ecological reclamation such as planting new floodplain forest crops in devastated river flood-plains etc. is a specific biotechnical type of reclamation.

Hydrological reclamation is becoming more and more common in the devastated areas after opencast coal mining or in depressions caused by underground mining. Such depressions often get flooded and water areas are created. The banks of such water areas are often transformed into beaches. Such a reclaimed landscape creates a recreational and sport potential for fishing, summer water sports, swimming as well as for winter sports; such areas are also used for other sports (motorsport race tracks, hippodromes, golf courses) or for recreational use (gardening cottages and plots), areas for business activities and so on.

The various reclamation methods, including recreational reclamation, have been mainly applied in the old industrial regions in the Rohr, the North-Bohemian Basin and in other places. However, the modern reclamation concepts, including the creation of a recreational landscape are only being implemented at the present time in the OstravaKarviná District.

The current survey of the reclamation projects has been conducted with the use of the method of analysis of zoning and planning documents of the municipalities in the Karviná region, mining, technological and reclamation plans of the OstravaKarviná Mining Company and with the use of the field survey method.

\section{Image of the Karviná region}

An image of a region may be defined as a picture or reputation in the awareness of citizens permanently living in a particular place and in the awareness of businesspeople, visitors and so on. The overall public impression of a city or region is formed and influenced by knowledge, information, experience as well as emotional ideas, feelings or opinions of the public on the particular place. The image of a particular place represents a simplification of a large quantity of associations and information connected to that place; however, it passes through some stages of development. The image can be changing in relation to various events and activities that happen in the place during a particular period of time. The image of the region is also influenced by the social and economic development, activity of important businesses, arrival and activities of various investors in production and nonproduction branches and also by their positive and negative effects affecting the landscape in mutual relations with impacts on the environment (KOTLER, 2001).

For many years, the image of the Karviná region has been connected to the black coal mining and to a substantially altered anthropogenic landscape affected by the mining activity. The mining activity has branded the region with an image of 
devastated, dirty landscape. The images of the affected landscape with all the consequences of undermining - subsidence, submerged subsidence depressions, contaminated rivers, refuse heaps, wastes, sludge tanks, a landscape mechanized with various industrial and storage facilities, a displaced, abandoned landscape contaminated with dust and smog - those images are deeply rooted in the minds of the local citizens as well as the general public. In spite of the many positive changes in the recent years related to the reclamation of the affected landscape, such associations have caused negative attitudes of the public to this region and have also led to its unfavourable demographic, migration and socioeconomic development. The City of Karviná itself has lost over 20 thousand citizens from the beginning of 1990s, after the phase of the dynamic population and socioeconomic growth during the socialistic development. The crucial socioeconomic problems that form the image of the Karviná region include a high long-standing unemployment rate, criminality, occurrence of pathological effects and so on. Lately, however, there is a real chance of a better life in this region, particularly in relation to the area of measures focused on the improvement of the environment.

\section{Development of the Mining Activity in the Karviná Region}

The Ostrava-Karviná District (OKD) is only a small part of the extensive coal Upper Silesia Basin that is mostly located in neighbouring Poland (more than $90 \%$ of the area). As for black coal mining, the region is one of the most significant in Europe. About $90 \%$ of the total black coal production in former Czechoslovakia was extracted in OKD until the end of 1980s; three quarters of the total extraction came from the Karviná part of the district. The black coal extraction in the Ostrava Region as well as in other parts of the Czech Republic was reduced at the beginning of 1990s, after the transformation of Czech mining. However, the Karviná region still holds a crucial position in black coal mining. At present, all black coal in the Czech Republic is extracted in the region by 4 mining companies. Only a negligible part of the extraction is produced in the Frýdek-Místek part of the district where there is only one mining plant in Stařrič still in operation (however, the mine is expected to close down in three years). The total production of caking and power coal has decreased from approximately 28 million tonnes to 9 million tonnes in the past twenty years (OKD 2014). The face working areas of the Karviná Mine (with plants in Karviná and Orlová-Lazy), Darkov Mine and ČSM Mine in Stonava represent the only viable black coal extraction area in the Czech Republic after the reduction processes. At present, black coal is extracted in the seams of the Karviná formation in depths of about 1,000 meters below the surface. The Karviná seams reach the thickness of up to 6 meters and the deepest extractable seam is over 10 meters thick in some places. Even though there are still reserves of high-quality coal (for about 20 years with the current extraction rate), it is currently very hard to predict the development of the exploitation of this material, and thus its social, economic, environmental and other consequences. The cost-effectiveness of mining is affected by many factors, such as price of the coal on global markets, crisis in the metallurgical and metal-working industry in the regions significant for the supplier-consumer relationships, the economic situation and operating costs of plants, costs of removal of mining damages in the concerned territory, costs of reconstruction of damaged surface objects, costs of decontamination and reclamation without which life in this territory would not be possible due to the devastation. In this respect, we can expect continuous reduction in the coal production, starting in Frýdek-Místek where the conditions for extraction are currently much worse and later in the Karviná region. However, the reduction in coal mining is connected with the termination of the negative effects of mining in the landscape and its subsequent use for other purposes.

\section{Negative influences of coal extraction in the landscape}

The territory of the Karviná face working areas has brought a substantially altered anthropogenic landscape affected by the mining activity. The landscape is devastated by subsidence and submerged subsidence depressions due to undermining; it is burdened with refuse dumps, sedimentation sludge traps and various industrial and storage premises. The landscape is seriously polluted with dust particles and other harmful substances and both surface and underground waters are also permanently polluted.

The visible by-product of coal mining is the production of waste rock - mine refuse. The waste used to be stored on the surface near the mines in waste heaps (the mines carried out up to 20 million tonnes of mine refuse into the landscape in 1980s). One tonne of extracted coal during development work created up to 1 tonne of waste 
rock (HAVRLANT J., 1999). The production of mine refuse was reduced by more than a half with the decline of mining in 1990s. In spite of that, millions of square meters of waste rock were stored at 10 large refuse dumps in the Karviná Region. More than 40 refuse dumps were gradually created during the history of coal mining there. The refuse heaps occupied an area of about 550 ha. The largest ones were located in Karviná - Doly (170 ha), Orlová, Doubrava and Louky. Some of them have been partially eliminated or reclaimed; others are being prepared for decontamination and biological reclamation and a balanced incorporation into the landscape. However, the refuse dumps have a very negative effect on the environment prior to reclamation as they pollute air with dust, devaluate land resources and overall aesthetic degradation of the landscape. However, the standard platform or conical dumps are not longer used. Lately, the waste rock is used to cover the extensive undermined and devastated localities, submerged subsidence troughs and areas that are being prepared for technical decontamination and reclamation. The number and extent of such areas, including compensating burrows, cannot be precisely quantified with regard to the fast changes and progress of the decontamination work. The waste rock from mines is now widely used as a building material in the reconstruction and construction of roads, bridges, railway objects or various terrain modifications of the devastated landscape and so on.

Fine wastes from coal preparation plants, flotative mine refuse and coal sludge (dust particles diffused in water) are also stored by the mines and together with the fly ash from power plants, these wastes are carried by pipelines into sedimentation tanks that are most often localized in the devastated areas in submerged subsidence troughs. In the Karviná region, those areas largely devastate the natural landscape. When the tanks are filled with sludge, they create large flat "terrain mirrors". The sludge tanks are the source of pollution of surface and underground waters and when dried out, they are a significant course of dust air pollution. In mid-1980s, there were 20 sedimentation tanks in the Karviná region; at the end of 1990s, there were 45 tanks with the total area exceeding 550 ha. The largest sludge tanks are located by the Karviná Mine (with an area exceeding 200 ha), by the Darkov Mine (160 ha) and by the ČSM Mine between Stonava and Louky nad Olší. In the past ten years, the area of the sedimentation tanks has decreased in relation to the decline of coal mining and the introduction of new coal sludge processing technologies. Many of the tanks are being eliminated and decontaminated. However, their final reclamation will not be possible until the mining activity stops in several years (HAVRLANT J., 2010).

Subsidence and the resulting overall devastation of the landscape are serious problems of the undermined territory. While subsidence affected just below a half of the Karviná face working areas, today the landscape affected by subsidence represents of up to $80 \%$ of the area (over $100 \mathrm{~km}^{2}$ ), out of which submerged areas cover about ten percent of the area. Majority of the twenty flooded depressions is used for storing coal sludge from the coal preparation plants. The surface water is thus heavily polluted.

Deep funnel depressions occurred in the subsided face working areas which led to gradual wetting and water logging of the subsidence troughs and resulting extensive devastation of the landscape. In many areas, subsidence caused gleying of the soil, decrease in the soil quality and subsequent decay of vegetation, including forest covers and so on. In the former Karviná - Doly district, an area most affected by mining, majority of its area contains problematic localities with submerged subsidence troughs and sludge pits. The devastating effects of mining are caused by the technology of controlled caving used for coal extraction. When the coal seams are exhausted, their upper walls are disturbed and then they break and fall down into the extracted area. The caving is then manifested by a subsidence through on the surface, with an area larger than the area of the caving into the exhausted seams under the ground. This harsh mining technology is used due to the economic factors, high costs of back filling of the exhausted seams and also due to the lack of material suitable for back filling. However, the Ostrava-Karviná Mining Company has to create financial reserves for the purchase of real estate, private land and houses in the areas affected by mining, to compensate the owners, to decontaminate and reclaim land and so on.

The total depth of subsidence from the beginning of mining is not known since subsidence was not systematically monitored until 1960s. However, it is demonstrable that the most prominent surface deformations were mainly registered in the former centre of Karviná - Doly in the face working area of the Karviná Mine where, for example, the locality by the former railway station on the major railway road in the former Czechoslovakia has decreased by more than 40 meters from mid-1960s until today. Other heavily devastated areas with subsidence exceeding 30 meters include the east part of 
Karviná - Darkov, Stonava and Louky nad Olší. Subsidence has caused vast deformations and destruction of many surface objects. The land relief slopes at the edges of the depressions which also causes sloping of surface objects and the formation of cracks. Subsidence has caused problems with drainage of the area, damage to the engineering communications and service pipelines, roads as well as the railway corridor from Bohumín through Karviná to Žilina etc. Between Karviná and Louky nad Olší, the railway road is continuously being repaired, roads re-laid, new embankments poured, watercourses stemmed and surface objects demolished. Extensive damage is also registered I other parts of Karviná, Orlová and Doubrava. The area of connected residential development in the territory of the Karvina face working areas dropped to approximately $3 \%$ due to the devastating impact of undermining. In the second half of the $20^{\text {th }}$ century, the new residential development concentrated outside the face working areas to Karviná - Nové Město that was not affected by mining.

\section{Changes in the utilization of landscape and current devastated area reclamation}

\subsection{Changes in the utilization of landscape in the Karviná region}

There have been radical changes in the utilization of landscape from the very beginning of coal extraction in the Karviná region. The arable land occupied over $70 \%$ of the territory until the mid$19^{\text {th }}$ century. The countryside quickly transformed into a mining and industrial landscape during the second half of the $19^{\text {th }}$ century. By 1950, the ratio of the arable land in the Karviná region dropped to the half. At present, the arable land only encompasses $4 \%$ of the total area, out of which permanent grassland covers approximately one quarter of the area (POPELKOVÁ, 2009). The forest area remains without any substantial changes despite the local devastation of vegetation due to the emission effects and permanent wetting of soil. At present, forests cover an area of about one thousand hectares; however, the three species composition is not satisfactory. Various self-seeding vegetation has settled in the territory affected by mining and on burrows. The original alluvial plain of the Olše River with an alluvial forest, rare fauna and a system of ponds in Louky nad Olší has been heavily devastated by the effects of undermining and resulting subsidence. The hydrographical ratios in the Karviná Region have changed significantly due to subsidence, particularly between Karviná - Louky - Horní Suchá - Orlová and Doubrava. The area of semi-natural vegetation with grassland, bushes and self-seeding tree species, which occur in about a quarter of the area, has been increasing in the affected areas during the last twenty-five years. However, these low-quality growths are important to keep the ecological stability of the territory, particularly in the biocorridor of Poolší.

\subsection{The reclamation of landscape in the Karviná region}

The reclamation of landscape in the Karviná region means time-demanding treatments that solve decontamination of the subsidence troughs, removal of old non-functional sludge tanks, treatment of burrows and so on. The reclamation also include the treatment and restoration of drainage channels, ponds and water reservoirs, reconstruction and relaying of traffic and engineering communications and service pipelines. The area may be reclaimed using various cultures, various methods, among others using hydrological reclamation, according to the agreements with the concerned municipalities and according to requirements of administrative authorities (BARTU゚ŇKOVÁ, 2012). Reclamation is executed according to the current zoning plans in compliance with the requirements of public administration.

Building new objects and residential quarters and the reconstruction of traffic and technical infrastructure are very expensive, often reaching amounts of billions of Czech crowns. Since 1990, over 8 billion Czech crowns have been invested into reclamation in the Karviná region. The government also participate in financing the eradication of the consequences of coal extraction. In the last ten years, several reclamation plans have been implemented, such as "Eradication of Old Burdens in the Ostrava-Karviná District" which was implemented within the reclamation programme run by the Moravian-Silesian Region. The project included ten large reclamation events. At present, reclamation of the devastated territory in about a quarter of the face working area (exceeding 1,000 hectares) is taking place: around the Karviná Brook, in Karviná - Darkov, Lipiny, Špluchov, Doubrava - Kozinec and in the sludge tanks in Orlová, Horní Suchá and Louky nad Olší. Today, the biological forestry and hydrological reclamation is being promoted rather than the formerly preferred agricultural reclamation, among others also for the purpose of a recreational use of the territory (ŠTYYS, 1998). One of the first important reclamation events was the extensive reclamation of the worst 
affected area in old Karviná - Doly, which also focused on the conservation of a cultural monument: the leaning Church of St. Peter of Alcantara (Fig. 2). Following actions focused on the reclamation of the landscape between Stonava (Křivý Důl location) and Horní Suchá where 3 breeding ponds were restored by hydrological reclamation and forests and arable land was reclaimed in their surroundings.

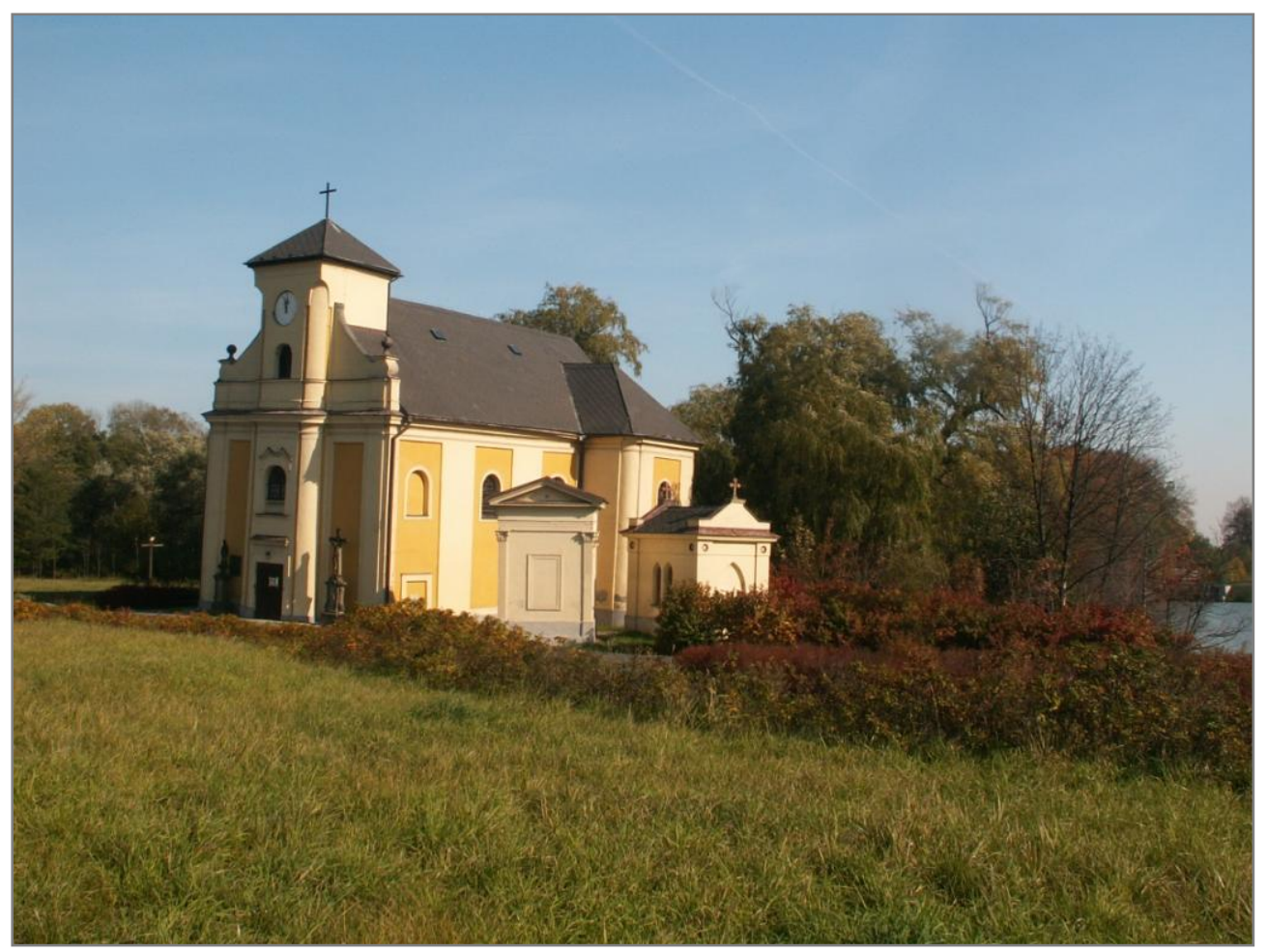

Fig. 2. The leaning Church of St. Peter of Alcantara, a cultural monument in the devastated and reclaimed area of Karviná - Doly (J. Havrlant, 2012)

There are thirteen decontamination and reclamation constructions in progress in the face working area in Louky nad Olší, between the main railroad from Karviná to Český Těšín and parallel Class I Road No. I/67. The works include altitudinal modifications, building dams and embankments of the road and the railway object; concurrently, five sludge tanks with an area exceeding 90 ha are being decontaminated. However, the sludge tanks can only be decontaminated partially as they are still used as operating tanks by the ČSM Mine and they will be used for the entire duration of the mine activity. The neighbouring locality Loucké rybníky, which used to be a protected landscape area, was heavily devastated by deep subsidence. The current reclamation focuses on creating a valuable natural landscape with a water body ( 95 ha) and an adjacent special-purpose forest (70 ha). Alluvial deciduous trees including the willow, English oak and hornbeam will be planted in the alluvial plain of the Olše River and other protective greenery, including the linden, ash and spruce, will be planted in its surroundings (MACHÁČEK, 2009). The proof of the ecological significance of natural water bodies as well as the submerged and reclaimed subsidence troughs is the occurrence of rare animal species that have returned to this devastated landscape after a long time: such as freshwater crayfish, scarce chaser, various fish species and so on. The decontamination and biological reclamation are also under way in the large submerged subsidence trough in the face working areas of the Karviná and Darkov Mines (Pilňok and Mokroš sludge tanks) and in Orlová Lazy and Doubrava - Kozinec (Fig. 3). The reclaimed burrows in those localities that are starting to be covered in vegetation also include a habitat of thermophilic plant species. An example of a purposeful combination of hydrological and biological reclamation is the creation of a functional water body near the Darkov Spa, suitable for recreational use (the Karviná Sea). The reclamation of the devastated area (140 ha) in the vicinity of the Darkov Mine (see Fig. 4) is implemented by the Ostrava-Karviná Mining Company with the support of the city council. A lake was created in the deep subsidence trough and biological reclamation with modification of banks and the surroundings of the water body is now under way. To shape and grass the terrain, the locality is now 
being colonized by trees and various accompanying vegetation. The water body is already being used by fishermen; but there are no recreational amenities yet. Even though its area, amenities or significance do not compare to the nearby Těrlická and Žermanická dams that have a broader tourist infrastructure and services for various leisure activities, the lake in Darkov has the potential to become a popular recreational zone, particularly for the citizens of Karviná and the neighbouring municipalities. When the subsidence stops in the following stage of the reclamation of the area in question, the plan is to build a car park, a kiosk and other additional recreational infrastructure.



Fig. 3. Actual and planned reclamations in the Karviná region

A unique example of successful reclamation of a mining landscape transformed into a brand new landscape for sports and recreational use is the reclamation project of the golf club in Karviná Lipiny. In 2010-2012, a new golf course with all the required facilities was built in place of a former large refuse dump situated between the Olše and Stonávka river streams after its gradual elimination and shaping and technical modifications of the terrain. The Karviná - Lipiny Golf Resort was created in the devastated landscape between two operating mines (see Fig. 5). The area affected by mining was reclaimed by the Ostrava-Karviná Mining Company using European Union funds. The new golf course by the Darkov Mine (with an area of $70 \mathrm{ha}$ ) is now used by professional athletes, beginners, tourists and the general public. The master 9-hole course $(3,570$ meters long) is now being extended to a top-quality 18-hole course.
The children's playground is expanding its services. The Olše River separates the golf course from the chateau landscape park (with an area of $35 \mathrm{ha}$ ) founded in Fryštát at the beginning of the 19th century. The entire area between Karviná - Fryštát, Lipiny and Darkov thus currently represents an attractive sports and recreational zone for the citizens as well as tourists. This zone also includes a modified dead channel of the Olše River (Fig. 6) with a character of a natural lake (with an area of 8 ha). The lake with a small dockyard, fishing opportunities and a nearby cycling path has a great recreational potential for the City of Karviná. Together with the area of the Darkov Spa (which, however, is currently struggling with economic problems), an extensive recreational complex has been created in Karviná (over 200 ha). Its seasonal attractiveness is increased by the expanding cycling path network that leads through the Euro-Region 
of Těšín Silesia into the Polish borderland. Also, the long-distance cycling path from the Silesian Beskydy Mountains through Český Těšín, Poolší and Karviná (see Fig. 7) to Bohumín is becoming more and more attractive. Other leisure activities are offered by the historic centre of Karviná - Fryštát with a reconstructed chateau, a large park (Fig. 8) as well as sports facilities of the city (ice stadium, multi-purpose sports hall, tennis courts, football pitch etc.). The expanding recreational and sports infrastructure has a positive effect on the image of the Karviná Region. Some of the old mining objects and mining pits with unique historic equipment also have a tourist potential (e.g. Michal Mine, Landek or the industrial complex of the Hlubina Mine and the Vítkovice Ironworks furnaces in Ostrava) as these are original technical monuments. Also, the closed-down pits in Karviná, such as the Gabriela Mine, unused saltwater mining waters and other have a potential that has not been explored yet. Other industrial objects, historic transportation equipment, mine delivery tracks between Karviná, Orlová and Ostrava also offer some opportunities for the development of specific forms of tourism with a potential for educational trails, thematic learning, excursion and cycling tourism.

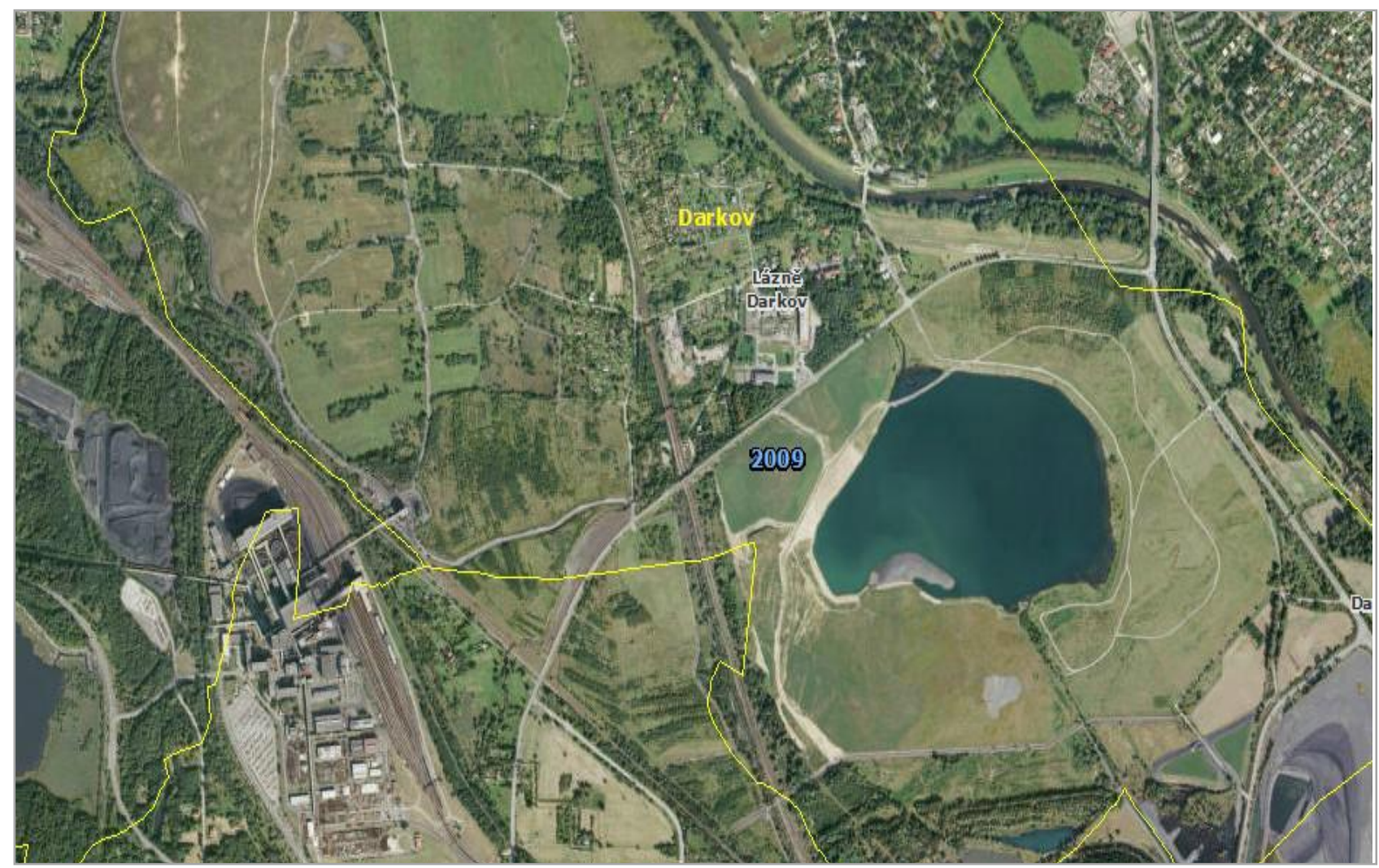

Fig. 4. The devastated and reclaimed area of Karviná - Darkov (www.kontaminace.cz)

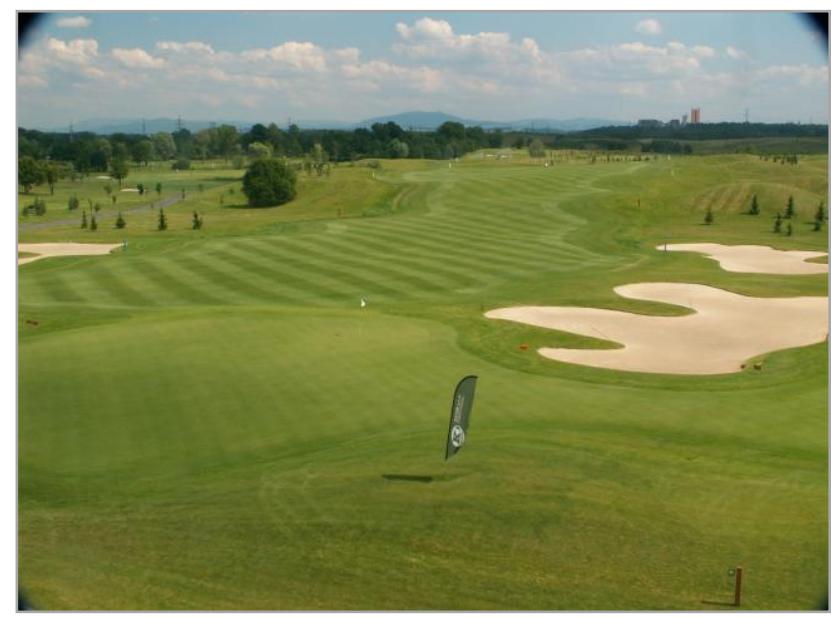

Fig. 5. The Karviná - Lipiny Golf Resort was created in the devastated landscape between two operating mines (J. Havrlant, 2014)

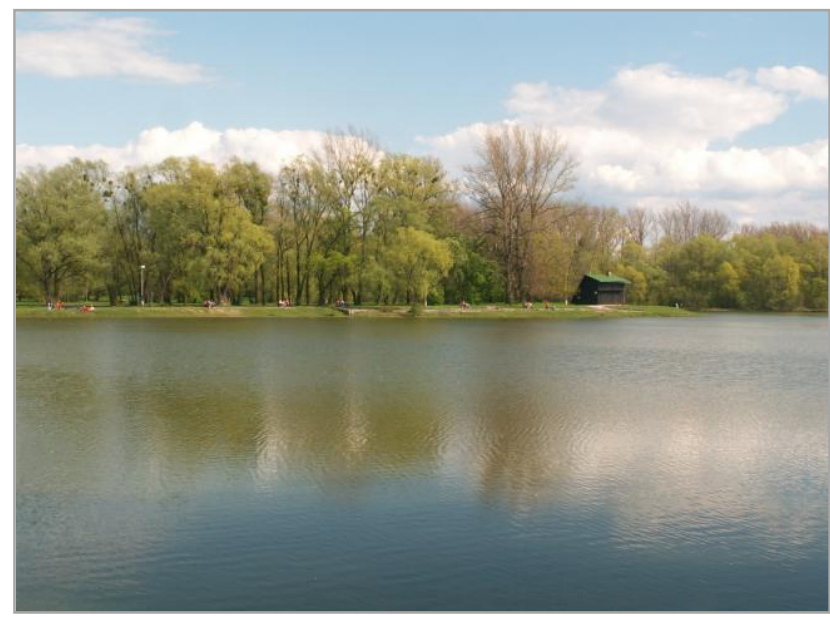

Fig. 6. Modified channel of the Olše River - a lake in the Karviná Park (J. Havrlant, 2014) 


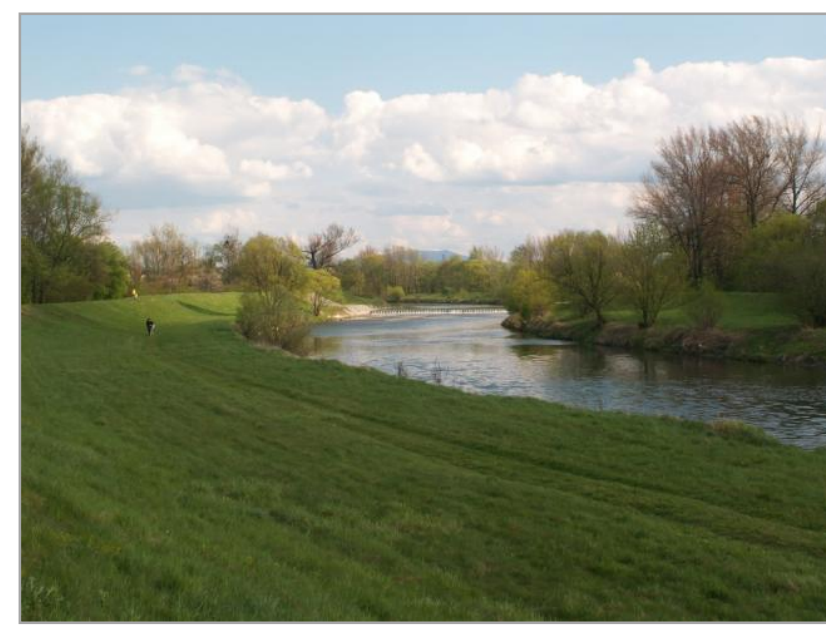

Fig. 7. Attractive cycling path along the Olše River in the face working area of Karviná - Darkov (J. Havrlant, 2014)

\section{Conclusion}

The expanding cooperation of the OstravaKarviná Mining Company with the private and public sector, the Municipal Council of Karviná and other regional and local stakeholders brings tangible positive results to the region after a long period of time. The cooperation shows the possibilities of coexistence of industry in the region and the possibilities of recreational utilization of the anthropogenic landscape; it allows seizing opportunities for the development of various forms of tourism, development of the essential infrastructure and services in the region that has been devastated by mining for many years. The implemented reclamation and other prepared revitalization measures focus on the creation and protection of a new cultural landscape by various development projects; the new landscape will be utilized for recreation and will have a positive impact on the overall improvement of the environment. The various methods of reclamation and changes in the functional utilization of the landscape provide the Karviná region with the long-awaited turn for the better and a positive change of the image of the City.

\section{References}

Bartůňková K. 2012. Rekultivace povrchových hnědouhelných dolů v severních Čechách. Geogr. rozhledy, 22, 2, ČGS Praha: 8-9.

Chmielewska M. 2009. Rewitalizacja starych okręgów przemysłowych. [in:] Kasprzak et al. [eds.] Badania podstawowe i aplikacyjne $w$ naukach geograficznych. UAM, Poznań: 57-61.

Chmielewska M. 2012. Kompleksowa i wielokierunkowa rewitalizacja zdegradowanej przestrzeni miejskiej w dzielnicy Hörde miasta Dortmund. Kształ. środ. geogr. $i$ ochr. przyr. na obsz. uprzem. i zurban., 44: 5-15.



Fig. 8. The Karviná - Fryštat Chateau and Park. 2014

(J. Havrlant, 2014)

Chuman T. 2013. Obnova krajiny po těžbě nerostných surovin. Geogr. rozhledy, 22, 2, ČGS, Praha: 10-11.

Domański B. 2000. Restrukturyzacja terenów poprzemysłowych w miastach. [in:] Rewitalizacja, restrukturyzacja, odnowa miast. Inst. GPK, Kraków.

Dulias R. 2004. Anthropogenic relief transformation in eastern part of Dabrowa Coalfield in the $20^{\text {th }}$ century. Anthropogenic aspects of landsc. transform., 3: 13-19.

Dulias R. 2010. Landscape planning in areas of sand extraction in the Silesian Upland, Poland. Landsc. and Urban Plann., 95, 3: 91-104.

Dulias R., Kupka R. 2010. Wpływ górnictwa na rzeźbę Katowic. Kształ. środ. geogr. i ochr. przyr. na obsz. uprzem. i zurban., 42: 26-31.

Fuchs M. 1999. Werkstatt für die Zukunft von Industrieregionen Die Internationale Bauausstelung Emscher Park im nördlichen Ruhrgebiet. [in:] Praxis Geographie, 29: 4649.

Ganser K. 1993. Die Internationale Bauausstellung Emscher Park. [in:] Erneuerung des Ruhrgebiets. Paderborn Schöningh.

Havrlant J. 1999. Negative Influences of Coal Extraction in the Mining areas of the Karviná region. Moravian geogr. reports, 7, 1: 56-60.

Havrlant J. 2010. Změny v hornictví a hornické krajiny Karvinska. Zpravodaj Hnědé uhlí, 2, VÚHU a.s., Most: 32-38.

Havrlant M. 1979. Antropogenní formy reliéfu a životní prostředí $v$ Ostravské průmyslové oblast., Spisy PF 41, PF Ostrava.

Havrlant M., Kincl M., Gerlich V. 1967. Př́rodní podmínky a současný stav vegetačního krytu na černouhelných haldách OKR. Spisy PF, Ostrava, SPN Praha.

Herter H. 2006. Emscher und Phoenix See, Dortmund. [in:] Masterplan Emscher - Zukunft. Das Neue Emschertal. Emschergenossenschaft, Essen.

Jankowski A.T. 2000. Anthropogenic relief transformation in the Upper Silesia Industrial Region. Anthropogenic aspects of landsc. transform., 1: 33-36.

Jankowski A.T., Havrlant M. 1999. Anthropogene Reliefveränderungen in Oberschlesien. [in:] Jordan, P. [ed.] Atlas Ost-und Südosteuropa, Aktuelle Karten zu Ökologie und Wirtschaft. Österreichisches Ost- und Südosteuropa Institut, Wien, 43.

Jankowski A.T. 1986. Antropogeniczne zmiany stosunków wodnych na obszarze uprzemysłowionym $i$ zurbanizowanym na przykładzie ROW. WNoZ Uniw. Śląski, Katowice.

Kopeć M. 2010. Rewitalizacja miejskich obszarów zdegradowanych. Wyd. Beck, Warszawa. 
Kotler P. 2001. Marketing, management. Překlad Dolanský, 5. rozšířené vydání, Grada, Praha.

Kupka R., Szczypek T., Wach J. 2005. Skutki 200-letniej eksploatacji węgla kamiennego w Katowicach. Geomorfologický sborník, 4: 11-14.

Kupka R., Frolik H., Dulias R. 2008. Zmiany rzeźby na obszarze górniczym zlikwidowanej kopalni KatowiceKleofas. Ksztat. środ. geogr. i ochr. przyr. na obsz. uprzem. i zurban., 39: 26-31.

Lorens P. 2010. Rewitalizacja miasta, planowanie i realizacja Politech., Gdańska, Gdańsk.

Macháček M. 2009. Pokračování hornické činnosti OKD a.s. Dolu ČSM vobdobí 2009-2020. [in:] Sborník z konf. Jihlava: 104-111.

Martinec P. et al. 2003. Atlas map vlivu útlumu hlubinné těžby černého uhlí v české části Hornoslezské pánve na povrch a životní prostředí. Documenta geonica, Ústav geoniky AV ČR, Ostrava.

Martinec P. et al. 2006. Termination of underground coal mining and its impact on the environment. Anagram Ostrava.

Mikulík O. et al. 2004. Soubor map vlivu útlumu hlubinné těžby černého uhlí na krajinu a životní prostředí Ostravska. Documenta geonica, Ústav geoniky AV ČR, Ostrava.

Muziol W.A., Behr I. 2003. Podręcznik rewitalizacji. Zasady procedury i metody działania procesów rewitalizacji. Warszawa.

Neumann U., Trettin L., Zakrzewski G. 2012. Tourismus im Ruhrgebiet - Chancen für kleine Unternehmen. RWI für Wirtschaftsforschung, Essen.
Popelková R. 2009. Retrospektivní analýza vývoje krajiny s využitím geoinformačních technologií. Disertační práce, VŠB - TU Ostrava, HGF.

Raclavský K. 2001. Hornická a pohornická krajina Horního Slezska. [in:] Sborník z konf., VŠB-TU, Ostrava: 246-248.

Šiřina P. 2003. Rekultivace území a recentních krajinných prvků, technická a biologická rekultivace. Strategie obnovy hornické krajiny, VŠB-TU, Ostrava.

Štýs S. 1981. Rekultivace území postižených těžbou nerostných surovin. SNTL, Praha.

Štýs S. 1989. Strategie a metody rekultivace území postižených těžbou nerostných surovin. disertační práce, Ústí nad Labem.

Štýs S. 1998. Rekultivace. Mostecká uhelná společnost.

Szczypek T. 1995. Anthropogenic relief in the eastern part of the Silesian Upland. Quaestiones Geogr., Spec. Iss., UAM, Poznań: 265-270.

Uberman R., Ostrega A. 2004. Sposoby rekultywacji $i$ zagospodarowania zwałowisk nadkładu i składowisk odpadów górniczych. Górn. Odkr., 46, 7/8: 80-87.

Vráblíková J., Vráblík P., Šoch M. 2009. Rekultivovaná krajina a její možné využití. FŽP Univ. J.E. Purkyně, Ústí nad Labem.

Výroční zpráva OKD. 2013. OKD, Karviná.

Walker L.R., Del Moral R. 2003. Primary succession and ekosystem rehabilitation. Cambridge Univ., Press. Cambridge.

Żmuda S. 1973. Antropogeniczne przeobrażenia środowiska przyrodniczego w konurbacji górnośląskiej. PWN, Warszawa, Kraków. 